\title{
Social tourism and its contribution to sustainable tourism
}

\author{
Scott McCabe \\ Nottingham University Business School
}

\begin{abstract}
Social tourism has gained wide recognition for the benefits it brings to citizens who would otherwise not be able to participate in tourism. Social tourism also delivers benefits to the tourism industry, to destinations and to provide a positive return on investment for governments. However, whilst policy makers extol the virtues of social tourism, programmes have struggled to remain resilient under pressure on public finances caused by the global financial crisis. This paper reviews the contributions of social tourism to sustainable tourism, critically assesses their potential to drive sustainable tourism in the future and makes recommendations for European policy makers.

Keywords: social tourism, sustainable tourism, tourism policy.

JEL classification: I38, L83, O15, Q01, Q20.
\end{abstract}

\section{Resumen}

El turismo social ha obtenido amplio reconocimiento por los beneficios que aporta a los ciudadanos que, de otro modo, no podrían participar en el turismo. El turismo social también ofrece beneficios a la industria del turismo, a los destinos y proporciona un retorno positivo de la inversión para los gobiernos. Sin embargo, mientras que los legisladores ensalzan las virtudes del turismo social, los programas han luchado por subsistir bajo la presión sobre las finanzas públicas causada por la crisis financiera global. Este documento revisa las contribuciones del turismo social al turismo sostenible, evalúa críticamente su potencial para impulsar el turismo sostenible en el futuro y hace recomendaciones para los responsables políticos europeos.

Palabras clave: turismo social, turismo sostenible, política turística.

Clasificación JEL: 138, L83, O15, Q01, Q20.

\section{Introduction}

Social tourism is an important pillar of the European tourism system, yet there remains widespread lack of awareness of the practices, policies and activities that comprise this phenomenon. Whilst in recent years there has been an increase in the amount of academic attention given to social tourism issues in a range of European contexts, the majority of this research has been focused on the benefits to individuals who participate in social tourism programmes. Importantly, research is emerging on the supply side factors and policies concerning social tourism, yet there is much less attention given to the more holistic issues and challenges surrounding social tourism and the implications arising from current developments for future provision. 
The purpose of this article is to address the important role that social tourism can play in helping achieve sustainability in the European tourism sector in the future. It argues that to remain competitive in the long term, European tourism destinations need to adopt strategies that will distribute demand more evenly in space and time to avoid overcrowding at peak times in the season. Similarly, destinations will need to become more differentiated and adopt sophisticated segmentation and targeting strategies, which should include a 'social segment' to ensure economic sustainability and efficient use of tourism resources. Whilst the evidence regarding social tourism's potential to contribute to a more sustainable tourism industry is still emerging, there are positive signs that this sector does offer good prospects in that regard. However, the article points out that recent policies, which have cut back on support for social tourism programmes will need to be reversed if these sustainability benefits are to be realised. The article argues for a more forward-thinking and holistic policy that includes social tourism initiatives taking into account the quadruple bottom line approach.

The paper begins by briefly defining social tourism and reviews the background to its development as a distinct form of tourism, to contextualise its place in the European tourism system. This is followed by a review of recent research on social tourism that has focused primarily on the benefits of various programmes and initiatives for individuals, and societies. This is important since the benefits approach has thus far been disconnected from the industry perspective. The article goes on to discuss and evaluate the limited literature on social tourism's role in contributing to sustainability in the industry. It concludes by making policy recommendations that could ensure that social tourism makes a full contribution to the sustainability of the European tourism industry in the future.

\section{Social tourism, definitions and contexts}

Social tourism concerns: "all activities, relationships and phenomena in the field of tourism resulting from the inclusion of otherwise disadvantaged and excluded groups in participation in tourism. The inclusion of these groups in tourism is made possible through financial or other interventions of a well-defined and social nature". (Minnaert, Diekmann and McCabe, 2012, 29). Many European societies have long since recognised the important restorative function that tourism plays for workers, and have enshrined the idea that there is a social right to travel and for rest from work, making provisions that enable the majority of their populations to enjoy access to holidays (EESC, 2006). In many respects these rights were defined within the context of worker's conditions through the industrialisation and factory production systems of the early to mid-twentieth century and the introduction of state welfare systems (Walton, 2013).

However, the social organisation of travel for leisure predates the mass factory production era. Indeed Thomas Cook's first tours were established through the idea 
that travel could be morally and spiritually enlightening and thus provided a positive use of leisure time (Minnaert, Dieckmann and McCabe, 2012). The largescale organisation of social movements, such as sports and health clubs and societies emerging in the late nineteenth century established the notion that leisure and recreation, and by extension, visits to spa and seaside resorts could facilitate positive outcomes for physical health (Walton 2012; Baumgartner, 2012).

Therefore, the origins of social tourism lay in the idea that tourism provides positive and important recuperative and educational benefits for ordinary people, and that such opportunities should be extended to all people in society. What followed in the post WWII era can be characterised into two major factors, first; the mass democratisation of travel opportunities, which enabled previously excluded members of society the ability to participate in international travel for the first time, and second; from the 1980s a transformation in European economic systems towards tertiary and technologically based knowledge economies. The nature of work as well as the needs for tourism and leisure have, for many been totally altered. However, throughout these transformations, the provision for social tourism continued to grow in many European countries, and in many different ways, such that by the early part of the new millennium, a wide range of policies, financial, social and organisational supports was directed into social tourism initiatives.

Tourism has become an industrialised system, an important pillar of the European economy and consequently the rationale for tourism participation has been fundamentally reconfigured. Many Europeans now regard the right to travel and tourism as a social entitlement (Diekmann and McCabe, 2015). Yet, since the global financial crisis, which began in 2007, there has been a further process of economic restructuring across Europe with high levels of unemployment, growing inequalities in income/wealth distribution and severe pressure on health and social care systems. The Equality Trust for example, states that the UK has a relatively high level of income inequality between the rich and poor in the society, with the top 20 per cent of society having 40 per cent of the total income, whereas the bottom fifth have only 8 per cent (https://www.equalitytrust.org.uk/scale-economic-inequality-uk). Poverty increasingly affects people who are in work, as there is an increase in part time work, zero hours contracts and the so-called 'gig' economy, whereby people work in a self-employed capacity. The UK is not a unique situation. According to the Borgen report, despite the economic upturn across Europe in recent years, poverty and unemployment in Spain is currently at 21 per cent of the population, with a third of all children being in poverty or at risk (Sarabia, 2016). Therefore, whilst there has been many changes in the economic cycles of Europe, and massive transformations in the economy and society, general long-term economic growth and development has not trickled down to all members of society. Tourism in Europe continues to grow and yet the drivers of this growth are from the demand amongst middle class citizens. A growing number of poorer members of society are just as likely to feel excluded from opportunities for travel and leisure as those people almost a century ago. 


\section{Social tourism research}

There has been a recent surge in research on social tourism, which has also witnessed an increase in interest outside of the European research community. From a relatively low base level of awareness and understanding of the range of systems and programmes for social tourism, there is now much more evidence emerging on the policy context for social tourism, the types of people supported by programmes, and the benefits associated with them. Table 1 presents an overview of recent research, which shows the extending range of studies beyond analyses of the demand for, and outcomes associated with social tourism for users or beneficiaries. The table summarises research papers published in English in the last two years. This is probably not an exhaustive list, but shows the increasing amount of research in social tourism and the increased diversity of studies. As the subject matures, there has been a broadening of research questions and focal areas of research, including studies based on economic methods, psychology, gerontology and education. There have also been a wide range of research methodologies and approaches applied to the study of social tourism. However, this rather simplistic overview also highlights

TABLE 1

REVIEW OF RECENT SOCIAL TOURISM RESEARCH

\begin{tabular}{|c|c|c|c|c|}
\hline Author(s) & Research focus & Methodology & Study context & $\begin{array}{c}\text { Main } \\
\text { contributions }\end{array}$ \\
\hline $\begin{array}{l}\text { Elisa Alén } \\
\text { González, Nieves } \\
\text { Losada Sánchez } \\
\text { and Trinidad } \\
\text { Domínguez Vila } \\
\text { (2017) }\end{array}$ & $\begin{array}{l}\text { Marketing and } \\
\text { segmentation: } \\
\text { Analyses the } \\
\text { attitudes and } \\
\text { preferences of } \\
\text { older Spanish } \\
\text { tourists, } \\
\text { comparing social } \\
\text { tourists with those } \\
\text { choosing other } \\
\text { packages. }\end{array}$ & $\begin{array}{l}\text { Survey method } \\
\text { using multinomial } \\
\text { logistic regression } \\
\text { analysis. }\end{array}$ & $\begin{array}{l}\text { Spanish older } \\
\text { tourists. }\end{array}$ & $\begin{array}{l}\text { Social tourists } \\
\text { have different } \\
\text { socio- } \\
\text { demographic } \\
\text { and behavioural } \\
\text { characteristics } \\
\text { to other older } \\
\text { package tourists. } \\
\text { Social tourism } \\
\text { programmes need } \\
\text { to adapt for a } \\
\text { changing market } \\
\text { needs. } \\
\end{array}$ \\
\hline $\begin{array}{l}\text { Kakoudakis, } \\
\text { McCabe and Story } \\
(2017)\end{array}$ & $\begin{array}{l}\text { Social cognitive } \\
\text { theory: } \\
\text { investigates the } \\
\text { possible changes } \\
\text { to self-efficacy } \\
\text { and job seeking } \\
\text { behaviour } \\
\text { amongst long- } \\
\text { term unemployed } \\
\text { people resulting } \\
\text { from social } \\
\text { tourism. }\end{array}$ & $\begin{array}{l}\text { Mixed methods, } \\
\text { pre-post-test } \\
\text { survey and } \\
\text { semi-longitudinal } \\
\text { qualitative } \\
\text { interviews. }\end{array}$ & $\begin{array}{l}\text { England, long } \\
\text { term unemployed } \\
\text { individuals. }\end{array}$ & $\begin{array}{l}\text { Social tourism } \\
\text { opportunities } \\
\text { create some } \\
\text { changes in self- } \\
\text { efficacy, and do } \\
\text { offer potential as } \\
\text { an alternative to } \\
\text { help long-term } \\
\text { unemployed } \\
\text { people back into } \\
\text { work. }\end{array}$ \\
\hline
\end{tabular}


TABLE 1 (cont.)

REVIEW OF RECENT SOCIAL TOURISM RESEARCH

\begin{tabular}{|c|c|c|c|c|}
\hline Author(s) & Research focus & Methodology & Study context & $\begin{array}{c}\text { Main } \\
\text { contributions }\end{array}$ \\
\hline $\begin{array}{l}\text { Cisneros } \\
\text { Martínez, McCabe } \\
\text { and Fernández } \\
\text { (2017) }\end{array}$ & $\begin{array}{l}\text { Economics: } \\
\text { Analyses the } \\
\text { contribution of } \\
\text { social tourism to a } \\
\text { more sustainable } \\
\text { seasonal spread of } \\
\text { tourist demand in } \\
\text { the low season. }\end{array}$ & $\begin{array}{l}\text { Econometric } \\
\text { methods, based } \\
\text { on monthly } \\
\text { accommodation } \\
\text { data. }\end{array}$ & $\begin{array}{l}\text { Spain, IMSERSO } \\
\text { programme for } \\
\text { older tourists. }\end{array}$ & $\begin{array}{l}\text { Provides evidence } \\
\text { to support the idea } \\
\text { that social tourism } \\
\text { can contribute } \\
\text { to economic } \\
\text { sustainability } \\
\text { through } \\
\text { combatting } \\
\text { seasonal } \\
\text { imbalances } \\
\text { in demand in } \\
\text { mass tourism } \\
\text { destinations. High } \\
\text { level of demand } \\
\text { from international } \\
\text { tourists in the } \\
\text { peak seasons } \\
\text { 'masks' some of } \\
\text { the benefits of } \\
\text { social, domestic } \\
\text { tourism. }\end{array}$ \\
\hline $\begin{array}{l}\text { Sedgley, Pritchard, } \\
\text { Morgan and } \\
\text { Hanna (2017) }\end{array}$ & $\begin{array}{l}\text { Psychology: } \\
\text { explores } \\
\text { mental health } \\
\text { and emotional } \\
\text { wellbeing of } \\
\text { families living } \\
\text { with Autism and } \\
\text { the effects of } \\
\text { supported tourism } \\
\text { opportunities. }\end{array}$ & $\begin{array}{l}\text { Qualitative } \\
\text { interviews: } \\
\text { Interpretive } \\
\text { Phenomenological } \\
\text { Analysis. }\end{array}$ & $\begin{array}{l}\text { Wales/England } \\
\text { Families with a } \\
\text { disabled (Autistic) } \\
\text { child(ren). }\end{array}$ & $\begin{array}{l}\text { For families living } \\
\text { with an autistic } \\
\text { child(ren), tourism } \\
\text { poses unique } \\
\text { challenges and } \\
\text { emotions. }\end{array}$ \\
\hline $\begin{array}{l}\text { Eusébio, Carneiro, } \\
\text { Kastenholz and } \\
\text { Alvelos } \\
(2017)\end{array}$ & $\begin{array}{l}\text { Marketing: } \\
\text { analyses the senior } \\
\text { social tourism } \\
\text { market, to identity } \\
\text { different types of } \\
\text { benefits. }\end{array}$ & $\begin{array}{l}\text { Quantitative } \\
\text { survey: benefit } \\
\text { segmentation. }\end{array}$ & $\begin{array}{l}\text { Portugal, older } \\
\text { people. }\end{array}$ & $\begin{array}{l}\text { Identifies a range } \\
\text { of different } \\
\text { ways in which } \\
\text { senior social } \\
\text { tourists benefit } \\
\text { from a holiday } \\
\text { experience. } \\
\text { Develops } \\
\text { marketable } \\
\text { segments and } \\
\text { proposes a more } \\
\text { differentiated set } \\
\text { of programmes. }\end{array}$ \\
\hline
\end{tabular}


TABLE 1 (cont.)

REVIEW OF RECENT SOCIAL TOURISM RESEARCH

\begin{tabular}{|c|c|c|c|c|}
\hline Author(s) & Research focus & Methodology & Study context & $\begin{array}{c}\text { Main } \\
\text { contributions }\end{array}$ \\
\hline $\begin{array}{l}\text { Estrada-González } \\
\text { (2017). }\end{array}$ & $\begin{array}{l}\text { Leisure studies: } \\
\text { to explore the } \\
\text { links between } \\
\text { learning and older } \\
\text { social tourist's } \\
\text { experience. }\end{array}$ & $\begin{array}{l}\text { Mixed qualitative } \\
\text { methods: } \\
\text { structured } \\
\text { interviews and } \\
\text { focus groups. }\end{array}$ & $\begin{array}{l}\text { Mexico, Older } \\
\text { people. }\end{array}$ & $\begin{array}{l}\text { Older people } \\
\text { learned from their } \\
\text { experience and } \\
\text { learned from each } \\
\text { other on the social } \\
\text { tourism trips. } \\
\end{array}$ \\
\hline $\begin{array}{l}\text { Backer and King } \\
\text { (2017). }\end{array}$ & $\begin{array}{l}\text { Marketing, } \\
\text { demographics. } \\
\text { Analyses the } \\
\text { participation } \\
\text { amongst } \\
\text { disadvantaged } \\
\text { groups in VFR } \\
\text { tourism. }\end{array}$ & $\begin{array}{l}\text { Quantitative, panel } \\
\text { data exploring } \\
\text { demographic } \\
\text { characteristics } \\
\text { and motivations } \\
\text { of national survey } \\
\text { data. }\end{array}$ & $\begin{array}{l}\text { Australia, general } \\
\text { population. }\end{array}$ & $\begin{array}{l}\text { Low socio- } \\
\text { economic status } \\
\text { groups are more } \\
\text { likely to be } \\
\text { VFR tourists. } \\
\text { VFR plays an } \\
\text { important role in } \\
\text { provision of travel } \\
\text { opportunities for } \\
\text { disadvantaged } \\
\text { Australians. Adds } \\
\text { dimensionality to } \\
\text { the social tourism } \\
\text { phenomenon. }\end{array}$ \\
\hline $\begin{array}{l}\text { Komppula, Ilves, } \\
\text { and Airey (2016). }\end{array}$ & $\begin{array}{l}\text { Management: } \\
\text { explores the } \\
\text { experiences } \\
\text { of diverse } \\
\text { social tourism } \\
\text { groups and the } \\
\text { implications. }\end{array}$ & $\begin{array}{l}\text { Ethnographic } \\
\text { approach, mixed } \\
\text { methods inc; } \\
\text { observation, } \\
\text { semi-structured } \\
\text { interviews, and } \\
\text { questionnaires. }\end{array}$ & $\begin{array}{l}\text { Finland, health } \\
\text { and wellbeing } \\
\text { holiday } \\
\text { programmes. }\end{array}$ & $\begin{array}{l}\text { The needs and } \\
\text { experiences of } \\
\text { diverse social } \\
\text { tourism groups } \\
\text { are very different. } \\
\text { Social tourism } \\
\text { programmes and } \\
\text { experiences are } \\
\text { relative to the } \\
\text { socio-cultural } \\
\text { context. Social } \\
\text { tourists experience } \\
\text { needs are similar } \\
\text { to mainstream } \\
\text { tourists. } \\
\end{array}$ \\
\hline $\begin{array}{l}\text { Ferrer, Sanz, } \\
\text { Ferrandis, } \\
\text { McCabe and } \\
\text { García (2016). }\end{array}$ & $\begin{array}{l}\text { Social and health } \\
\text { policy: assesses } \\
\text { the links between } \\
\text { active ageing } \\
\text { and tourism } \\
\text { participation. }\end{array}$ & $\begin{array}{l}\text { Quantitative, } \\
\text { survey data and } \\
\text { SEM. }\end{array}$ & $\begin{array}{l}\text { Spain, older } \\
\text { people's self- } \\
\text { reported health } \\
\text { and travel } \\
\text { behaviour. }\end{array}$ & $\begin{array}{l}\text { Older tourists are } \\
\text { more likely to } \\
\text { be more active } \\
\text { and have better } \\
\text { health than } \\
\text { non-travellers. } \\
\text { Makes the case for } \\
\text { supporting senior } \\
\text { travel to reduce } \\
\text { health and social } \\
\text { care costs. }\end{array}$ \\
\hline
\end{tabular}


TABLE 1 (cont.)

REVIEW OF RECENT SOCIAL TOURISM RESEARCH

\begin{tabular}{|c|l|l|l|l|}
\hline \multicolumn{1}{|c|}{ Author(s) } & Research focus & Methodology & Study context & \multicolumn{1}{c|}{$\begin{array}{c}\text { Main } \\
\text { contributions }\end{array}$} \\
\hline $\begin{array}{l}\text { Sedgley, Pritchard } \\
\text { and Morgan } \\
\text { (2015). }\end{array}$ & $\begin{array}{l}\text { Gerontology and } \\
\text { critical tourism: } \\
\text { explores the } \\
\text { experiences of } \\
\text { older people and } \\
\text { the links between } \\
\text { social tourism and } \\
\text { wellbeing. }\end{array}$ & $\begin{array}{l}\text { Critical, } \\
\text { person-centred } \\
\text { qualitative inquiry, } \\
\text { interviews. }\end{array}$ & UK, older people. & $\begin{array}{l}\text { Social tourism } \\
\text { contributes to } \\
\text { social wellbeing, } \\
\text { increases } \\
\text { confidence and } \\
\text { outlook for the } \\
\text { future, alleviated } \\
\text { isolation, stress } \\
\text { and loneliness and } \\
\text { mundane daily } \\
\text { life. }\end{array}$ \\
\hline $\begin{array}{l}\text { Bos, McCabe and } \\
\text { Johnson (2015). }\end{array}$ & $\begin{array}{l}\text { Social and } \\
\text { education policy: } \\
\text { explores the links } \\
\text { between social } \\
\text { tourism and } \\
\text { learning. }\end{array}$ & $\begin{array}{l}\text { Education and } \\
\text { learning styles, } \\
\text { qualitative } \\
\text { semi-structured } \\
\text { interviews and } \\
\text { focus groups. }\end{array}$ & $\begin{array}{l}\text { UK, children } \\
\text { and low income } \\
\text { families. }\end{array}$ & $\begin{array}{l}\text { Children from low } \\
\text { income families } \\
\text { had positive } \\
\text { outcomes from } \\
\text { their supported } \\
\text { holiday. A range } \\
\text { of different } \\
\text { learning types and } \\
\text { styles could be } \\
\text { linked to tourism, } \\
\text { depending on the } \\
\text { type of holiday } \\
\text { experience. }\end{array}$ \\
\hline Pagan, R (2015). & $\begin{array}{l}\text { Disability studies: } \\
\text { assesses the } \\
\text { outcomes of travel } \\
\text { for people with } \\
\text { disabilities. }\end{array}$ & $\begin{array}{l}\text { Quantitative, } \\
\text { panel data. }\end{array}$ & $\begin{array}{l}\text { Germany, people } \\
\text { with disabilities. }\end{array}$ & $\begin{array}{l}\text { Shows that people } \\
\text { with disabilities } \\
\text { are more likely to } \\
\text { have higher levels } \\
\text { of life satisfaction } \\
\text { resulting from } \\
\text { a holiday than } \\
\text { people who do not } \\
\text { have disabilities. } \\
\text { Provides support } \\
\text { for tourism for all } \\
\text { policies. }\end{array}$ \\
\hline
\end{tabular}

the concentration of research on the demand side of social tourism, with hardly any studies focusing on either the supply side perspective or on more holistic analyses of the relationships between social tourism and sustainability issues.

The increased attention given to social tourism issues may partly be attributed to the inclusion of social tourism amongst the policy initiatives of the EU, through the Calypso programme. Another factor explaining the rise in academic attention given to social tourism may be an increased attention given to the issue in English language publications. A further factor might be an awareness amongst the academic 
community of the need for a deeper focus on heterogeneous sectors of the tourism system. Whatever the reasons, the surge of recent research demonstrates the potential of social tourism to deliver many benefits to excluded people in society. Yet we have little understanding of whether social tourism can also help lead to a more sustainable tourism sector in the future.

\section{Sustainable development and tourism}

As previously mentioned, the sustainable development agenda has been an explicit feature of international policymaking for over 30 years, spearheaded by the publication of the Brundtland Report 'Our Common Future' (World Commission on Environment and Development [WCED], 1987). This recast the previous focus on economic growth into a broader conceptualisation encompassing multiple dimensions, including economic, but also social, cultural, environmental. This shift recognised the complexities of social systems (e.g. poverty, social exclusion, unemployment, human rights, and protection of environmental resources), as important factors that also determine how development occurs (e.g. Sharpley, 2000). The main ideology behind the Bruntdland Report, is that the worlds resources should be put to use to ensure that human wellbeing improves at a global level, the utilisation of the resources should not be at a level that compromises the ability of future generations to have access to the resources that they need for their wellbeing. The focus of sustainable approaches to development therefore should necessitate a focus on the long-term over short-term economic gains.

At the turn of the new Millennium, after a decade of conferences, which was kickstarted with the Rio Earth Summit in 1992, the UN gathered world leaders together to sign a declaration which became known as the Millennium Development Goals. These were to: eradicate extreme poverty and hunger, achieve universal primary education, promote gender equality and empower women, reduce child mortality, improve maternal health, combat HIV/AIDS, Malaria and other diseases, ensure environmental sustainability and, develop a global partnership for development (UNDP no date). The MDGs was a significant step by the world's community to take a more balanced and human-centred global perspective on how development should be oriented towards improvements in the lives of people. And yet, they have been criticised for being driven largely by the agendas of the OECD countries, and for being too target driven, and narrow in focus, not reflecting the complex challenges of the $21^{\text {st }}$ Century (e.g. Fukuda-Parr, 2016).

However, the UN recognises that despite this refocusing, and all the positive steps taken to inculcate a broad-based perspective on development, the sustainability debate has often been classified as a purely environmental issue, and one which is subservient to an orientation globally on economic growth (UN 2010). The fifteen year programme of work attached to the MDGs ended with the establishment of the Sustainable Development Goals in 2015. This expanded set of 17 ambitious 
goals sought to usher in a more balanced approach that included the perspectives of developing nations, and a greater recognition of the inter-connected nature of the challenges and issues facing the world, including climate change, equitable development, environmental sustainability and poverty, health and wellbeing (UN no date).

Somewhat mirroring the subtle changes in emphasis being played out in relation to sustainable development, the literature on sustainable tourism has evolved over the decades. In his treatise on international tourism development and impacts, the Swiss sociologist Jorst Krippendorf argued that the growth of international tourism would continue until it reached a level of demand, which would have negative effects on the lives of people living in destination regions (Krippendorf, 1987). Although not the first academic to highlight the range and types of consequences arising out of tourism development, Krippendorf noted that the tourism industry would need to put in place policies and strategies, including marketing that would reduce these negative consequences for tourists as well as local people.

Yet in line with the general sustainable development, research on sustainable tourism has over the long term focused on environmental issues, particularly protection and amelioration of environmental impacts, and the consequences of climate-change (Bramwell and Lane, 1993; Lu and Nepal, 2009). This has resulted historically in an emphasis on environmental pillars with much less emphasis on socio-cultural or economic dimensions of sustainable development. This situation is beginning to change however in recent debates, and the focus on academic research does not reflect that emphases placed in European policy. Diekmann and McCabe (2011) highlight the transitions in European tourism policy over recent years, contextualising tourism policy in relation to social tourism. They point out that since 2006, the European Commission for Enterprise and Industry's 'Renewed Tourism Policy' focused on the economic growth perspective on the European tourism industry. Yet this was followed by the Tourism Sustainability Group that published a report taking a more holistic perspective, emphasising three main areas that aligned with sustainable development principles; economic prosperity, social equity and cohesion and, environmental and cultural protection (see the Tourism Sustainability Group, 2007). Diekmann and McCabe trace the shift in emphasis in tourism policy from one that was either broadly focused on supporting economic growth from the industry, or in relation to social tourism in particular, as being based in social cohesion and shared European values. However, by the time the EC established the Calypso programme of funding for social tourism, there was a more holistic orientation that related economic and social sustainability as being integrated. Calypso firmly grounded the rationale for social tourism in the likely economic benefits to destinations and governments (revenue from greater tourism spending, increased employment, sustained employment, increases in tax revenues and so on) (eCalypso, 2016).

Therefore, following the evolution of thinking on sustainable development, there is an increasing recognition amongst the tourism academy that it is impossible to 
compartmentalise the economic, social and environmental aspects of the operation of tourism as set of activities of both humans and an 'industry(ies'). Accordingly, the role that social tourism can play in the achievement of a more sustainable and equitable tourism system, better aligned with the ideals of the sustainable development goals, should be an important consideration in the development of European tourism policy in the future.

\section{Social tourism and sustainable development}

Social tourism is concerned with the inclusion of economically and socially disadvantaged populations in travel and tourism, through interventions (either policy or financial or other support) of a well-defined social nature (McCabe, Minnaert and Diekmann, 2012). As mentioned previously, recent attention on social tourism has emphasised the important socio-psychological benefits that can be realised for disadvantaged groups through participation in tourism (e.g., Smith and Hughes, 1999; Minnaert et al., 2009; McCabe and Johnson, 2013; Morgan, Pritchard and Sedgley, 2015). Some of this research has focused on the potential that social tourism can be so profound that the individual benefits could have knock-on benefits to society, such as increased job-seeking behaviour amongst the unemployed (Kakoudakis, McCabe and Story, 2017). Whilst this recent evidence is still emerging, the direction of this research highlights the multi-dimensionality of the issues and the need for an integrated approach concomitant with the sustainable agenda.

And whilst the recent research on social tourism has done much to progress the case for social tourism, there is a danger that the emphasis on the welfare benefits of interventions for disadvantaged and excluded groups, masks the important contribution that social tourism could play in relation to the sustainability agenda. Social tourism is much more than welfare. As the Calypso programme demonstrated, the emphasis on individual benefits can usefully be considered in conjunction with the need for a more balanced tourism economy in Europe, which minimises the negative environmental impacts. Evidence from a range of established social tourism programmes in continental Europe (e.g. IMSERSO and INATEL social tourism programmes in Spain and Portugal, respectively) shows that social tourism makes an equally important contribution to the generation of employment and to the economic growth of destination communities. Indeed, social tourism can help ameliorate some of the worst negative effects of seasonality (European Commission, 2010; CisnerosMartínez, McCabe and Fernández-Morales; 2017; Eusébio, Carneiro, Kastenholz and Alvelos, 2016).

For example, in a recent study taking an economic modelling perspective on the contributions of social tourism to counter-seasonal effects of the tourism industry, Cisneros-Martínez, McCabe and Fernández-Morales (2017) found evidence to support the assertion that social tourism can help smooth out the intense fluctuations in demand in the coastal Spanish tourism resort regions. Tourism is the primary 
economic sector of Spain, accounting for between 12 and 25 per cent of total employment and contributing 11 per cent of total national GDP. However, the highly season nature of employment in the industry creates a situation whereby a high proportion of jobs are lost each winter. Since social tourism programmes are often directed towards economic efficiency (the ready availability of spare capacity in the industry at a very low cost), they can offer very effective solutions to such destination regions that are searching for counter-seasonal tourism efforts. Cisneros-Martínez et al found that by focusing on domestic tourism demand patterns, and specifically on those trips generated by the IMSERSO programme for senior Spanish citizens, that administers the financial aid for this social tourism activity, there is a noticeable effect on the seasonal concentration of tourism demand (2017). In addition, their study examined the effects on season employment and found that social tourism did have a similar effect on the concentration of employment in the Hotel industry. In other words, the IMSERSO programme helps to spread demand more evenly, which could be considered to exert less pressure on the environmental resource, and has economic benefits for the regional economies, creating more stable and sustainable employment, in addition to the benefits felt by holidaymakers. And yet, the IMSERSO programme has suffered from incremental budget reductions since the onset of the global financial crisis, and which has had a decremental impact on seasonality.

Several countries such as Spain, Portugal, Belgium and France, have shown that social tourism can be considered more than purely a welfare issue. For example, Eusébio, Carneiro, Kastenholz and Alvelos (2013), examined the economic impacts of health tourism programmes and found that they were effective in leading to cost savings for the public authorities in Portugal, and in a later study (2016), examined the economic contribution of senior tourism programmes provided by INATEL Foundation on the economic development of tourism destinations. They found that the economic contributions to destinations outweighed the costs of the programme based on an input-output model of the Portuguese economy and that social tourism can help diversify and restructure the destination economy, in addition to creating jobs, generating income and contributing to the development of the destination. The economic sustainability issue is fundamentally important since previous researchers have highlighted the spiralling effects that can accompany a decline in visitor numbers to coastal destinations, leading to declining living standards, decreases in investment and in infrastructure, resort restructuring towards a low-wage economy and social exclusion (Agarwal and Brunt, 2006). Despite the obvious sustainability challenges associated with the coastal tourism resorts, mass tourism development and the often (not always) peripheral location in relation to urban centres, many European holiday destination resorts have successfully diversified sufficiently. Indeed, one of the most intractable issues associated with social tourism is the sometimes lack of perceived congruence between the image a destination wishes to portray to its main markets, and the image that might be associated with social tourism (such as poverty and social exclusion) (Diekman, McCabe and Minnaert, 2012). Perhaps 
one way in which destinations could overcome issues of image incongruity is to focus on the social sustainability aspects of social tourism, relating to the sustainable development goals agenda.

The complimentary notions of sustainable actions and goals and social tourism extend well beyond issues for destination image. Social tourism reduces some of the inadequacies of the market-based tourism economy, so for example, if social tourism reduces seasonal concentration of demand, there would perhaps be less pressure to promote the high season to such an extent that 'overtourism' occurs in the peak seasons. The stress of too-high levels of demand on destination infrastructure and environments exacerbates social and environmental problems. Additionally, social tourism is mostly domestic tourism and although there is little evidence to date, an assumption can be made that this results in smaller carbon dioxide emissions compared to international travel, particularly involving air transport. Certainly in the UK context, much social tourism activity is dependent on public transport infrastructure and in many other ways, such as the use of more eco-friendly accommodation, such as hostels and caravans (see Baumgartner, 2012). Furthermore, the numbers of social tourists are generally significantly smaller than the peak tourism market, which brings fewer negative effects regarding the carrying capacity of destinations.

In one of the few studies that have discussed social tourism within the context of sustainability, Ryan (2002, p. 17) stressed that "in addressing the issues of sustainability concepts akin to social tourism need to be applied". That is to say that tourism development should take a holistic perspective in the same way that social tourism, as a marginal, but important cog in the overall system, has evolved an holistic appreciation of the ways that tourism can produce multiple, interconnecting, positive outcomes. When considering the relationships between development, particularly sustainable development, and wellbeing, in the case of tourism we must consider the quality of life of residents, and also the wellbeing of visitors as being of equal merit. And, in considering the importance of quality and availability of environmental resources for tourism, these should be put in context of the economic arguments for their protection and maintenance.

\section{Conclusions}

A connection between the social, economic and environmental aspects of tourism and the role that social tourism could play in delivering a more sustainable future for the industry is not new. Haulot, writing in 1985, in the Journal of Environmental Studies, argued that tourism:

"...when it is animated by social aims, supported by a permanent, active will to work for human betterment, an instrument and a technique at the service of a living culture open to all, and respectful from the outset of those very factors that gave it birth, tourism becomes a positive element fully 
integrated with the development and improvement of our planet. It becomes the champion of the natural environment without which it would perish. It learns to valorize human variety and all the delightful differences in culture, tradition, architecture and way of life because it is conscious of how much it gains from every tiniest shade of human experience" (Haulot, 1985, 222).

In setting out an explicitly social agenda for all tourism, but within the ideological notion that tourism should be accessible and enjoyed by everyone in society, Haulot positions social tourism as intrinsic to a sustainable tourism system. The impacts of tourism were just beginning to become more widely understood, and the Brundtland report, setting out the framework for the development of sustainable tourism was on the horizon (published in 1987). What has happened subsequently has been much progress, but against a context of massive expansion in tourism activity globally, which has made sustainable tourism development goals to seem further out of reach. Social tourism has also struggled to reach its full potential. There have been peaks and flurries of activity, expansion and contraction of programmes over the last 30 years. Currently, the picture is mixed, with new developments, but also contraction of well-established initiatives, due to cut-backs in government funding.

There remains very little academic research into the potential for social tourism to contribute to a more viable and sustainable tourism system. There is a need for the continuance of the programmes and better evidence on the ways social tourism can create useful outcomes for tourists that in turn generate benefits to the societies that provide the funding and support. Whilst this evidence is beginning to emerge, it also needs to be complemented with research on the societal benefits from social tourism in destinations, alongside economic and environmental sustainability evaluation studies. If tourism is to remain competitive, continue to deliver gross value added contributions to national economies above the average for different economic sectors, which is sustainable in the longer-term, more holistic studies on the potentials offered by domestic social tourism in the low season are required. In an era of constrained public finances, policy makers need convincing evidence if investment in social tourism is to increase. However, given the real possibilities for sustained research in this direction over the next few years, based on the recent trajectory of evidence into the benefits of social tourism, there is real hope that the case can be made for such increased investment, leading to a fairer and more sustainable tourism system, one that works for all in society.

\section{References}

[1] AGARWAL, S. and BRUNT, P. (2006). «Social exclusion at English seaside resorts». Tourism Management, 27, 654-70.

[2] BAUMGARTNER, CH. (2012). «Social tourism and sustainability». In S. McCabe, L. Minnaert and A. Diekmann (Eds.), Social Tourism in Europe: Theory and Practice, Channel View, 166-177. 
[3] BOS, L.; McCABE, S. and JOHNSON, S. (2015). «Learning never goes on holiday: an exploration of social tourism as a context for experiential learning». Current Issues in Tourism, 18 (9), 859-875.

[4] BRAMWELL, B. and LANE, B. (1993). «Sustainable tourism: An evolving global approach». Journal of Sustainable Tourism, 1 (1), 1-5.

[5] CISNEROS MARTÍNEZ, J. D.; McCABE, S. and Fernández, A. (2017). «The contribution of social tourism to sustainable tourism: a case study of seasonally adjusted programmes in Spain». Journal of Sustainable Tourism (forthcoming). http://dx.doi.org/ 10.1080/09669582.2017.1319844.

[6] DIEKMANN, A. and McCABE, S. (2011). «Systems of Social Tourism in the European Union: A Comparative Study». Current Issues in Tourism, 14 (5), 417-430.

[7] DIEKMANN, A.; McCABE, S. and MINNAERT, L. (2012). «Social tourism today: stakeholders, and supply and demand factors». In S. McCabe, L. Minnaert and A. Diekmann (Eds.), Social Tourism in Europe: Theory and Practice, pp. 35-47.

[8] ECALYPSO (2016). «eCalypso - Tourism for all». Retrieved from http://ecalypso.eu/.

[9] ESTRADA-GONZÁLEZ,A.E. (2017). «Social tourism, senior citizens, and education». World Leisure Journal, DOI: 10.1080/16078055.2017.1393872.

[10] EQUALITY TRUST, THE (no date). «The Scale of income inequality in the UK». Downloaded from: www.equalitytrust.org.uk/scale-economic-inequality-uk: accessed 04/12/17.

[11] EUROPEAN COMMISSION (2010). Calypso study on social tourism: Greece. Retrieved from http://ec.europa.eu/DocsRoom/documents/6936?locale=en Accessed 06/12/2017.

[12] EUROPEAN ECONOMIC AND SOCIAL COMMITTEE (2006). Opinion of the European Economic and Social Committee on Social tourism in Europe. Retrieved from http://eur-lex.europa.eu/legalcontent/EN/TXT/? uri=CELEX\%3A52006IE1155.

[13] EUSÉBIO, C.; CARNEIRO, M. J.; KASTENHOLZ, E. and ALVELOS, H. (2013). «The economic impact of health tourism programmes». In A. Matias, P. Nijkamp and M. Sarmento (Eds.), Quantitative Methods in Tourism Economics, 153-173, Heidelberg: Physica.

[14] EUSEBIO, C.; CARNEIRO, M. J.; KASTENHOLZ, E. and ALVELOS, H. (2016). "The impact of social tourism for seniors on the economic development of tourism destinations». European Journal of Tourism Research, 12, 5-24. Retrieved from http://ejtr.vumk.eu/index.php/volume12/281v12125theimpactoofsocialtourismforsenior sontheeconomicdevelopmentoftourismdestination.

[15] ELISA A. GONZÁLEZ; NIEVES L. SÁNCHEZ AND TRINIDAD D. VILA (2017). «Activity of older tourists: Understanding their participation in social tourism programs». Journal of Vacation Marketing, 23 (4), 295-306.

[16] FERRER, J. G.; SANZ, M. F.; FERRANDIS, E. D.; McCABE, S. and GARCÍA, J. S. (2016). «Social tourism and healthy ageing». International Journal of Tourism Research, 18 (4), 297-307.

[17] FUKUDA-PARR, S. (2016). «From Millennium Development Goals to the Sustainable Development Goals: shifts in purpose, concept, and politics of global goal setting for development». Gender and Development, 24 (1), 1-24.

[18] HALL, D. R. and BROWN, F. (2006). Tourism and Welfare: Ethics, Responsibility and Sustained Wellbeing. Wallingford, Oxford, CABI. 
[19] HAULOT, A. (1985). «The environment and the social value of tourism». International Journal of Environmental Studies, 25, 4, 219-223.

[20] KAKOUDAKIS, K.; McCABE, S. and STORY, V. (2017). «Social Tourism and Selfefficacy». Annals of Tourism Research, 65, 108-121.

[21] KRIPPENDORF, J. (1987). The Holiday Makers: Understanding the Impact of Leisure and Travel. London, William Heinemann.

[22] KOMPPULA, R.; ILVES, R. and AIREY, D. (2016). «Social holidays as a tourist experience in Finland». Tourism Management, 52, 521-532.

[23] LU, J. and NEPAL, S. K. (2009). «Sustainable tourism research: An analysis of papers published in the Journal of Sustainable Tourism». Journal of Sustainable Tourism, 17 (1), 5-16.

[24] McCABE, S. and DIEKMANN, A, (2015). «The Rights to Tourism: Reflections on Social Tourism and Human Rights». Tourism Recreation Research, 40 (2), 194-204.

[25] McCABE, S. and JOHNSON, S. (2013). «The happiness factor in Tourism: subjective well-being and social tourism». Annals of Tourism Research, 41, 42-65.

[26] McCABE, S. (2009). «'Who needs a holiday?' Evaluating social tourism». Annals of Tourism Research, 36 (4), 667-688.

[27] McCABE, S.; MINNAERT, L. and DIEKMANN, A. (Eds.) (2012). Social Tourism in Europe: Theory and Practice. Bristol, Channel View.

[28] MINNAERT, L.; DIEKMANN, A. and McCABE, S. (2012). «Defining Social Tourism and its historical context». In S. McCabe, L. Minnaert and A. Diekmann (Eds.), Social Tourism in Europe: Theory and Practice, 18-31. Bristol, Channel View.

[29] OECD (2011). How's Life? Measuring Well-Being. OECD Publishing.

[30] PAGAN, R. (2015). «The contribution of holiday trips to life satisfaction: the case of people with disabilities». Current Issues in Tourism, 18 (6), 524-538.

[31] SARABIA, D. (2016). Spanish Sketches: An Overview of Poverty in Spain. Retrieved from: https://borgenproject.org/poverty-in-spain/ Accessed 04/12/17.

[32] RYAN, C. (2002). «Equity, management, power sharing and sustainability - issues of the 'new tourism'». Tourism Management, 23 (1), 17-26.

[33] SEDGLEY, D.; PRITCHARD, A.; MORGAN, N. and HANNA, P. (2017). «Tourism and autism: Journeys of mixed emotions». Annals of Tourism Research, 66, 14-25.

[34] SEDGLEY, D.; PRITCHARD, A. and MORGAN, N. (2015). «Social tourism and well-being in later life». Annals of tourism Research, 52, 1-15.

[35] SHARPLEY, R. (2000). «Tourism and sustainable development: Exploring the theoretical divide». Journal of Sustainable Tourism, 8 (1), 1-19.

[36] SMITH, V.; HUGHES, H (1999). «Disadvantaged families and the meaning of the holiday». International Journal if Tourism Research, 1 (2), 123-133.

[37] UNITED NATIONS (2010). Sustainable Development: From Brundtland to Rio 2012. New York, United Nations.

[38] UNITED NATIONS DEVELOPMENT PROGRAMME (no date). «Millennium Development Goals». Accessed from http://www.undp.org/content/undp/en/home/ sdgoverview/mdg_goals.html retrieved: 06/12/2017.

[39] UNITED NATIONS (no date). «Sustainable Development Goals». Accessed from: http://www.un.org/sustainabledevelopment/sustainable-development-goals/ retrieved: 06/12/2017. 
[40] WALTON, J. K. (2013). «'Social tourism’ in Britain: History and prospects». Journal of Policy Research in Tourism, Leisure and Events, 5 (1), 46-46.

[41] WCED (1987). Our common future. Report of the World Commission on Environment and Development. In G. H. Brundtland (Ed.). Oxford: Oxford University Press. 